ROCZNIKI PEDAGOGICZNE

Tom 12(48), numer $1-2020$

DOI: http://dx.doi.org/10.18290/rped20121-11

ALINA RYNIO

\title{
AKTUALNOŚĆ MYŚLI PEDAGOGICZNEJ O. JACKA WORONIECKIEGO
}

Wychodząc z założenia, że czas życia i twórczości o. Jacka Woronieckiego (1878-1949), jakkolwiek obejmuje okres trwania koszmarnej i z niczym nieporównywalnej II wojny światowej, zasadniczo nie odbiega od wyzwań, z jakimi przychodzi się zmagać każdemu pokoleniu, i mając na uwadze problem zawarty w temacie niniejszego opracowania, swoją wypowiedź zogniskuję wokół trzech kwestii. Formułuję je następująco:

1. Kim był i co takiego pozostawił po sobie o. Jacek Woroniecki, że w siedemdziesiątą rocznicę jego śmierci chcemy o nim pamiętać i uznajemy za stosowne, aby pamięć tę przekazać potomnym?

2. Do czego można sprowadzić jego wkład w rozwój pedagogiki jako takiej, a pedagogiki katolickiej w szczególności?

3. Za sprawą czego jego poglądy dotyczące rozumienia kwestii wychowania i roli wychowawcy wytrzymują próbę czasu?

Mam świadomość, że kwestie te w żaden sposób nie wyczerpują bogactwa jego myśli pedagogicznej, a tym bardziej filozoficznej.

\section{POTRZEBA PAMIĘCI O OSOBIE I NAUCZANIU \\ O. JACKA WORONIECKIEGO}

Dlaczego zatem potrzebujemy pamięci o o. Jacku Woronieckim i jego nauczaniu? Odpowiedź na tak postawione pytanie jest dosyć oczywista. Pamięć o nim, podobnie jak pamięć o licznej rzeszy intelektualistów pozostających pod jego urokliwym wpływem, w tym światowej sławy filozofa

Dr hab. Alina RYNIO - Katedra Pedagogiki Chrześcijańskiej, Instytut Pedagogiki Katolickiego Uniwersytetu Lubelskiego Jana Pawła II, Al. Racławickie 15, 20-950 Lublin; e-mail: memor@kul.pl; ORCID: https://orcid.org/0000-0003-4113-7620. 
i logika o. Innocentego Józefa Bocheńskiego, o. Feliksa Wojciecha Bednarskiego, Stefana Świeżawskiego, kardynała Stefana Wyszyńskiego czy kardynała Karola Wojtyły - papieża Jana Pawła II jest nam potrzebna, by zachować świadomość tego, kim był on sam i jego uczniowie i aby mogło być kontynuowane to, czemu służył. Potrzebę pamięci o Jacku Woronieckim sytuuję w kontekście współczesności, w której wraz z niebywałym postępem technologicznym obserwować można zagubienie człowieka w kwestiach podstawowych. Szczególnie uwidacznia się ono w formie uzyskania odpowiedzi na pytanie o istotę człowieczeństwa i własną tożsamość płynącą ze spotkania z Chrystusem. W świecie, w którym żyjemy, z jednej strony mamy do czynienia $z$ człowiekiem globalnym, tolerancją, wolnością i poszanowaniem, a $\mathrm{z}$ drugiej - $\mathrm{z}$ dominacją skrajnego indywidualizmu, egocentryzmu, zamknięciem na drugiego i jego odmienność, upadkiem kultury, moralności i samotnością.

Kim zatem był urodzony 21.12.1878 r. w Lublinie i z nim wielorako związany o. Jacek Woroniecki? Z relacji prof. Grażyny Karolewicz wynika, że ten wybitny teolog, filozof i pedagog pochodzący ze znanego rodu Woronieckich, pobierający gruntowne wykształcenie najpierw w IV Gimnazjum Męskim w Warszawie, a po odbyciu służby wojskowej w pułku huzarów w Warszawie od 1899 we Fryburgu Szwajcarskim, w 1906 r. został wyświęcony na kapłana i powierzono mu wykłady z Pisma Świętego w Seminarium Duchownym. W tym czasie został sekretarzem biskupa lubelskiego Franciszka Jaczewskiego. W 1907 r. ponownie wyjechał do Fryburga, gdzie w dwa lata później obronił rozprawę doktorską z teologii i wstąpił do zakonu dominikanów w San Domenico di Fiesole, gdzie otrzymał imię zakonne Jacek ${ }^{1}$.

\footnotetext{
${ }^{1}$ Szczegółowy biogram o. Jacka Woronieckiego znaleźć można w: G. KAROLEWICZ, Nauczyciele akademiccy Katolickiego Uniwersytetu Lubelskiego w okresie międzywojennym, t. II, Lublin: Redakcja Wydawnictw KUL, 1996, s. 236-238. Na temat życia o. Woronieckiego zob. też. M. MıŁAwICKI, W poszukiwaniu mistrza i autorytetu duchowego. Ojciec Jacek Woroniecki OP we wspomnieniach wspótbraci zakonnych, uczniów i przyjaciól; http://www.repozytorium.uni.wroc.pl/ dlibra/publication/84726/edition /79789/content?ref=desc (dostęp: 25.04.2019), który przywołuje: Z. MAZUR, Udział ojca Jacka Woronieckiego w reformie polskiej prowincji dominikanów (19091945), w: Dominikanie. Szkice z dziejów zakonu, red. M.A. Babraj, Poznań: W drodze, 1986, s. 417-424; R. PolAK, Jacek Woroniecki. Życie i twórczość naukowa, Człowiek w Kulturze 1999, nr 12, s. 219-240; Człowiek, moralność, wychowanie. Życie i myśl Jacka Woronieckiego OP, red. J. Gałkowski, M.L. Niedziela, Lublin: TN KUL, 2000; R. MALISZEWSKI, Ojciec Jacek Woroniecki, Cywilizacja 2002, nr 2, s. 37-43; K. KALINOWSKA, Jacek Woroniecki o spoleczeństwie i państwie, Lublin: Fundacja Servire Veritati Instytut Edukacji Narodowej, 2005; I.Z. BŁESZYŃSKA, O. Jacek Woroniecki 1878-1949. Dominikanin, wychowawca, patriota, Lublin: Fundacja Servire Veritati Instytut Edukacji Narodowej, 2006; Sluga Boży ojciec Jacek Woroniecki uczy, red. M.L. Niedziela,
} 
„W 2018 roku - jak pisze Ryszard Polak - podjął misję odnowienia życia religijnego Polaków na terenie zaboru rosyjskiego" (2011, s. 838). W latach 1919-1929 był zaangażowany na KUL. Wykładał na wszystkich czterech wydziałach, a w latach 1922-24 piastował funkcję rektora, był także wicerektorem, prodziekanem i dziekanem Wydziału Teologicznego, a także dyrektorem Konwiktu Księży Studentów. Przez większość swego życia był nauczycielem. Dziś po siedemdziesięciu latach od jego śmierci trzeba dodać i to, że o. Jacek Woroniecki, będąc wybitnym wykładowcą Papieskiego Uniwersytetu Świętego Tomasza z Akwinu Angelicum w Rzymie i Kolegium Filozoficzno-Teologicznego Ojców Dominikanów (najpierw we Lwowie, a następnie w Warszawie-Służewie i Krakowie), poświęcając całe swoje kapłańskie życie kwestii wychowania moralnego, został ogłoszony sługą Bożym, zaś jego poglądy pedagogiczne szczególnie w tym, co się tyczy podmiotu wychowania, rozumienia i typów wychowania, formułowania istoty wychowania chrześcijańskiego i pedagogiki katolickiej, definiowania celów i zasad wychowawczych, a także określania cech nauczyciela i wychowawcy, są godne poznania, gdyż nie straciły na aktualności.

\footnotetext{
Woroniecki zajmował się głównie problematyką teologiczną i pedagogiczną, a jego poglądy oparte były na gruntownej znajomości filozofii klasycznej: starożytnej (Arystoteles), średniowiecznej (Tomasz z Akwiny), współczesnej (J. Maritain). Korzystał także z osiągnięć współczesnej mu pedagogiki, psychologii, filozofii społecznej i teologii. Doskonale znał literaturę piękną, zarówno polską jak i obcą, wielokrotnie wypowiadając się na tematy literackie (Polak 2011, s. 839).
}

Nie dziwi zatem, że dla wielu sobie współczesnych, nie wyłączając hierarchii kościelnej, był niekwestionowanym autorytetem i mistrzem. Będąc znakomitym nauczycielem dusz ludzkich i kierownikiem życia duchowego nie tylko dla swoich współbraci zakonnych, ale i dla innych, szczególnie zaś dla młodzieży akademickiej i inteligencji, potrafił indywidualizować metody i podejścia. Gdziekolwiek się pojawiał, wnosił światło i pokój.

Wychowywał - jak napisze po latach o. Feliks Wojciech Bednarski - promieniowaniem osobistego charakteru, którym z łatwością podbijał sobie serca,

\footnotetext{
Warszawa: Maurycy Lucjan Niedziela, 2006; P. TARASIEWICZ, Sylwetki wielkich Polaków. Jacek Woroniecki OP, Studia Ełckie 2007, nr 9, s. 363-368; K. STĘPIEŃ, Śladami Mistrzów. Woroniecki, Bednarski, Krąpiec, Cywilizacja 2009, nr 30, s. 210-212; Próba biografii Jacka Woronieckiego OP i jego Wyznania, red. M.L. Niedziela, Lublin: Gaudium, 2011. Ponadto w 1959 r. Towarzystwo Naukowe KUL z okazji dziesiątej rocznicy śmierci Woronieckiego jego osobie poświęciło z. 1-2 Rocznika Teologiczno-Kanonicznego zatytułowany Ethos perenne ku czci O. Jacka Woronieckiego.
} 
przykładem własnego życia, konferencjami, rekolekcjami, kazaniami do ludu, słuchaniem spowiedzi, wykładami oraz swą twórczością literacką, którą niemal bez reszty poświęcił zagadnieniom wychowawczym, gdyż nawet jego studia z innych dziedzin miały służyć wychowaniu (Bednarski, 1982, s. 59).

Myśl Woronieckiego w pedagogice jest ciągle aktualna i rozpatrywana przez wielu współczesnych badaczy, między innymi: przez wspomnianą już Grażynę Karolewicz (2006, s. 149-158), Jarosława Horowskiego (2007; 2016, s. 231-244), Stanisława Gałkowskiego (1998; 2003) Barbarę Kiereś (2017), Janinę Kostkiewicz (2009, s. 11-27; 2013, s. 97-128.), Marię M. Boużyk (2015, s. 221-240; 2016, s. 357-373.), Ryszarda Polaka (1999, s. 45-62; 214240; 2004, s. 137-147; 2017), Bogdana Czupryna (1999, s. 23-29), Jadwigę L. Jabłońską (1996, s. 93-104), Katarzynę Kalinowską (1999, s. 177-187), Beatę Karpińską (2002, s. 126-132), Mikołaja Krasnodębskiego (2009, s. 2958), Remigiusza Króla (2015), Longina Marchlewicza (1999, s. 91-94), Katarzynę Olbrycht (2007), Kacpra Radzckiego (2011), Marka Rembierza (2000, s. 207-233), Arkadiusza Robaczewskiego (1999, s. 31-35), Alinę Rynio, Małgorzatę Tomczyk (2012, s. 13-47), Ryszarda Skrzyniarza (2017, s. 295320), Krzysztofa Ślezińskiego (2016, s. 175-187), ks. Edwarda Walewandra (2007), s. Gabrielę Wistubę (2003, s. 235-246) i wielu innych autorów, którzy w swoich publikacjach odwołują się do treści zawartych w jego twórczości. Przywołani autorzy szczególną uwagę skupiają na zagadnieniach związanych $\mathrm{z}$ wychowaniem, wychowawcą $\mathrm{i}$ autorytetem, antropologicznymi postawami wychowania, aktualnością katolickiej etyki wychowawczej, formowaniem osoby ludzkiej, a także wykorzystują treści edukacyjne, wychowawcze i personalistyczne zawarte w pismach o. Woronieckiego.

\section{WKŁAD O. WORONIECKIEGO W ROZWÓJ PEDAGOGIKI}

Należąc do grona najwybitniejszych filozofów, teologów, etyków i pedagogów pierwszej połowy XX wieku, Woroniecki niewątpliwie był jednym z głównych przedstawicieli, twórców i odnowicieli pedagogiki katolickiej. Sformułował całościowy system wiedzy o moralności i wychowaniu człowieka oparty na przesłankach racjonalizmu i duchowości chrześcijańskiej. System wychowania oparł na nauce św. Tomasza z Akwinu. Przez sobie współczesnych uznawany za doskonałego wychowawcę i duchowego przewodnika polskiej inteligencji, nazywając po imieniu jej braki i zaniedbania, ukazywał drogi rozwoju osobowego ku wszelkim dostępnym formom 
doskonałości. Pragnął wychować ludzi na osoby „ze szlachetnym charakterem", dla których istnieją prawdziwe ideały: wiary, nadziei, miłości, prawdy i dobra. Wychowując, kształcił mądrych i zdrowych moralnie członków Kościoła i społeczeństwa, a wszelkie wskazówki, jak to należy czynić, pozostawił w Katolickiej etyce wychowawczej składającej się z dwóch tomów: Etyki ogólnej (2000a) i dwuczęściowej Etyki szczegółowej (2000b).

Jego twórczość pisarska i naukowa jest niezwykle bogata. Obecnie mamy dostęp do ponad dwustu pozycji wydanych drukiem. Pomimo licznych wznowień jego dzieł i wydawaniu wciąż nowych, współczesna znajomość myśli filozoficzno-etycznej i pedagogicznej jest znikoma. W kontekście podjętego tematu na uwagę zasługują nie tylko teksty źródłowe, ale także pozycje okolicznościowe popularyzujące jego osobę i dokonania. Niezwykle bogate $\mathrm{w}$ treść są materiały konferencji naukowej z racji dziesiątej rocznicy śmierci, jak również konferencji sprzed 20 lat, która także odbyła się w Katolickim Uniwersytecie Lubelskim $\mathrm{z}$ okazji pięćdziesiątej rocznicy jego śmierci (2000). Jednak wiele dzieł tego wybitnego dominikanina dalej pozostaje w manuskryptach.

Godny uwagi jest fakt, że kilkanaście z drukowanych prac o. Woronieckiego podejmuje problematykę wychowawczą i pozwala wyodrębnić chrześcijański model kształcenia i wychowania. W jego założeniu miał być to model spójny, efektywny, uniwersalny. Nosił miano paedagogia perennis. Zręby tego modelu znaleźć możemy w artykule Pedagogia perennis, zamieszczonym w Przegladzie Pedagogicznym z 1924 r., i we wspomnianej dwutomowej Katolickiej etyce wychowawczej. Jego analiza pozwala wyodrębnić antropologiczno-etyczno-teologiczne podstawy chrześcijańskiego wychowania, a także zobaczyć związek pedagogiki z etyką, teologią moralną i socjologią. Nadto możemy dostrzec opis umysłowych i zmysłowych władz człowieka, rolę sumienia i wolności w życiu osoby, jak również wyczerpujący opis sprawności moralnych i ich miejsca w kształtowaniu moralnego charakteru człowieka. Woroniecki, tworząc zręby owej pedagogii, dobrze wiedział, że tak jak chrześcijaństwo nie jest zbiorem formul, lecz niezmiennie oparte jest na przestrzeni wyznaczonej przez stronę przyrodzoną i nadprzyrodzoną, stronę modlitwy i aktywności, namysłu oraz społecznego zaangażowania, tak też system paedagogiae perennis musi uzgodnić w swoim teoretycznym kształcie wszelkie możliwe perspektywy postrzegania rzeczywistości.

Propagowana przez o. Jacka Woronieckiego paedagogia perennis uwzględniała utrzymujące się wówczas tendencje w kulturze, życiu społecznym, nauce, filozofii i teologii moralnej. Zadziwia prostotą, z jaka określa 
status quo rzeczywistości, oraz powagą, z jaką traktuje odniesienie tez teoretycznych do praktyki życia. Wielkość systemu paedagogiae perennis polega nie tylko na owej złożoności mieszczącej szereg różnych pespektyw, ale także na odwadze podejmowania trudu realizacji teoretycznych założeń. Pedagogia ta, propagując określoną wizję człowieka, powstaje na mocy owej spójności praktyki i teorii, postrzegania ważności spraw świata, w którym się żyje. Dlatego może ona wnieść istotny wkład w przywrócenie publicznego charakteru prawdzie, tak by religia i polityka nie instrumentalizowały się nawzajem.

Ojciec Woroniecki zasługuje na pamięć potomnych także dlatego, że pokazuje, jak być profesjonalnym filozofem, nie zrywając kontaktu z rzeczywistością społeczną, teologiczną, etyczną, historyczną. Zawężenie etyki i pedagogiki do sfery teoretycznej uważa za nieporozumienie, podobnie jak nie widzi możliwości całkowitego wyodrębnienia pedagogiki z etyki. Jeżeli ma to miejsce, to - jego zdaniem - zarówno pedagodzy katoliccy, jak i pedagodzy innego światopoglądu popadają w dydaktyzm, psychologizm, intelektualizm moralny, laksyzm czy probabilizm. Woronieckiemu chodziło o szczególne umocowanie pedagogiki w etyce, psychologii, teologii moralnej czy socjologii. Związek ten miał pomóc przezwyciężyć problem pokutujących, nie tylko w jego czasach, indywidualizmu, intelektualizmu i woluntaryzmu. Proponowany przez niego system paedagogiae perennis cechuje nie tylko jedność celów etyki i pedagogiki, ale również jedność celów kształcenia i wychowania. W wychowawczej teorii Woronieckiego nie tyle chodziło o pytanie ,czy”, lecz o „ile”. Ile intelektu, woli, kazuistyki, moralności, psychologii, ile teorii, ile praktyki, ile wyobraźni, ile radości, ile nakazu, ile zakazu umieścić należy w systemie wychowawczym. Odpowiedź była i aktualnie jest niezmiernie trudna. Zdaniem analizującej tę kwestię Wandy Kamińskiej, odpowiedź ta „uzależniona jest od naszej dojrzałości, z jaką postrzegamy Chrystusa". Jej zdaniem odniesienie do Jego prawdy stanowi w koncepcji kształcenia i wychowania Woronieckiego rodzaj niewidzialnego fundamentu, na którym opiera się olbrzymia różnorodność rozstrzygnięć zarówno teoretycznych, jak i praktycznych. Fundament ten nie tylko że nie krępuje, ale też nie usztywnia tego systemu i pozwala na poszukiwanie najlepszych rozwiązań w zakresie prawdy o wychowaniu i kształceniu rozwijających się tutaj kolejnych pokoleń. „Dynamika tego modelu jest uzgodniona $\mathrm{z}$ jego statyką. Pełne mądrości i miłości spojrzenie na Chrystusa pozwala na odkrywanie określonego typu: racjonalności, moralności, koncepcji człowieka" (Kamińska, 2000, s. 143). 
W ujęciu Woronieckiego współczesna etyka, zarówno teoretyczna, jak i praktyczna, a więc także pedagogika, jest skażona dwoma redukcjonizmami: pierwszym z nich jest moralny intelektualizm, a drugim antropologiczny indywidualizm. Intelektualizm moralny polega na tym, że „rozumowi nie tylko przypisuje się pierwszeństwo przed wolą, ale że całą działalność moralną sprowadza się niemal wyłącznie do rozumowania, z wykluczeniem działalności czynników pożądawczych, a przede wszystkim woli”. Jego zdaniem taka postawa wobec postępowania moralnego człowieka sprawia, że wychowanie utożsamia się z wykształceniem oraz sprowadza się je jedynie do nauczania prawd odnoszących się do postępowania moralnego. Zapomina się - pisze Woroniecki - „że wiedzieć jest czymś koniecznym, aby móc i działać, ale ono nie wystarcza, trzeba jeszcze chcieć i umieć systematycznie i wytrwale chcieć, a tej umiejętności nie nabywa się drogą nauczania, czyli oddziaływania intelektualnego” . Jak podkreśla z naciskiem: „n a le ży uczyć słowem, ale wychowywać czynem”. Ten aspekt pedagogiki jest perłą starożytnej greckiej nauki o cnotach jako stałych sprawnościach do podejmowania czynów moralnie dobrych. Poznanie aretologii, czyli nauki o cnotach, zaprowadziło współczesną pedagogikę do wspomnianego intelektualizmu, ten zaś utorował drogę indywidualizmowi, co z kolei spowodowało, że w pedagogice zaniedbano problematykę związaną z kwestiami oraz celami życia społecznego (Woroniecki, 2000b, s. 143). Opisująca i komentująca te kwestie Wanda Kamińska (s. 138), zauważa, że

\footnotetext{
w systemie tym jest miejsce na taką złożoność, która nie jest możliwa do zbudowania i ustrukturyzowania bez Osoby Jezusa Chrystusa, bez Jego prawdy, bez Jego prostoty. Stąd jeśli mamy być kontynuatorami myśli o. Jacka Woronieckiego, to z całą pewnością musimy odkryć ową złożoność przestrzeni aktualizacji człowieka. Jest to możliwe dzięki znajomości współczesnego kształtu dylematów pedagogicznych oraz pytań, które stawia współczesna antropologia filozoficzna, etyka, socjologia, kulturoznawstwo, psychologia.
}

Wizja wychowania proponowana przez o. Woronieckiego wskazuje na potrzebę kochania Boga w sposób wolny i stwarzania we współczesnym świecie „uczłowieczających” przestrzeni, w których będzie szanowana godność i wolność każdego człowieka.

Mając na uwadze to, co Woroniecki wnosi do pedagogiki, trudno nie zauważyć jego szczególnej roli w rozwój filozofii wychowania i pedagogiki katolickiej. Wystarczy w tym względzie szczegółowo zapoznać się z jego publikacjami. Odnośnie do pedagogiki katolickiej stwierdza, że stanowi ona ,system naukowy wychowania i nauczania nie tylko zupełnie zgodny 
z teologią i filozofią chrześcijańską, ale ściśle z nimi związany i wysuwający w ich świetle z doświadczenia wychowawczego zasady". Odpowiedzialny pedagog katolicki musi znać dorobek poznawczy własnej tradycji, a także wszystkie błędne doktryny wychowawcze i ich kontekst myślowy, którym jest tradycja idealizmu. Przypomina, że w pedagogice chrześcijańskiej naczelnym wychowawcą jest sam Bóg, z którym w Kościele ,jesteśmy niejako organicznie połączeni w jedno ciało mistyczne” oraz podkreśla „moc wychowawczą Eucharystii”. Dodaje, że dla pedagogiki katolickiej istotna jest nauka o grzechu pierworodnym i jego pozostałościach w ludzkiej naturze, a szczególnie o wadach głównych jako jego przejawach. Pedagogika ta musi być chrystocentryczna, centralnym punktem jej analiz w odniesieniu do przedmiotu wychowania musi być Chrystus. Woroniecki w analizie procesu wychowania człowieka wskazuje na cnoty wlane człowiekowi wraz z łaską. Cnoty te jako cnoty teologiczne, a wśród nich wiara, nadzieja i miłość, powodują w naszych władzach - rozumie i woli - stałe usposobienie w stosunku do samego Boga. Zauważa w związku z tym, że wychowanie chrześcijańskie polega na harmonijnym połączeniu czynnika przyrodzonego i nadprzyrodzonego, co sprawia, że sprawności nabyte drogą ćwiczenia „spajają się $\mathrm{w}$ jedną całość $\mathrm{z}$ udzielonym duszy z góry stałym usposobieniem nadprzyrodzonym do tych samych czynów". Owocem wewnętrznego powiązania pierwiastka przyrodzonego i nadprzyrodzonego jest charakter chrześcijański. Ten ,pełny rozwój osobowości chrześcijanina wymaga $z$ jednej strony mocnego podłoża w przyrodzonych podstawach charakteru, z drugiej zaś głębokiego przeniknięcia ich, czyli przebóstwienia, nadprzyrodzonymi pierwiastkami łaski" (tamże).

Woroniecki był przeciwnikiem indywidualizmu i subiektywizmu poznawczego, zwłaszcza w wydaniu Kartezjusza i I. Kanta. Jego zdaniem są to doktryny fałszywie interpretujące naturę ludzkiego poznania oraz działania, a przez to również szkodliwe dla pedagogiki i etyki oraz mają antyspołeczny, destruktywny charakter. Pośrednio wpływają na szerzenie się postaw egoistycznych oraz osłabiają religijność jednostek. Przedmiotem krytyki Woroniecki uczynił także partykularyzm poznawczy, indywidualizm etyczny, intelektualizm etyczny. Ponadto zwalczał naturalizm, doktryny sentymentalistyczne i wszelkie postawy fideistyczne. Był przeciwnikiem egalitaryzmu, za fałszywą uznawał ideologię liberalną i ideologię socjalistyczną. W jego mniemaniu ideologie te, nie szanując człowieka, ani należnych mu praw, niosą śmierć cywilizacji. Korzystając z własnego doświadczenia, w swoich pismach podejmował zagadnienie patriotyzmu i nacjonalizmu. 
Uważał, że miłość ojczyzny i narodu jest obowiązkiem każdego człowieka. Analizując strukturę ludzkiego działania, zauważał, że istotną rolę odgrywają w nim zarówno wola, jak i rozum, stąd stał na stanowisku, że nie można owych władz rozpatrywać oddzielnie, zwłaszcza wtedy gdy dokonujemy moralnej oceny ludzkich działań.

Właściwie trudno nie zgodzić się $\mathrm{z}$ taką interpretacją. Trudno też nie zauważyć szczególnej roli o. Jacka Woronieckiego w rozwoju pedagogiki katolickiej. Wystarczy w tym względzie szczegółowo zapoznać się z jego publikacjami w szczególności zaś z Programem pedagogiki katolickiej opublikowanym w Ateneum Kapłańskim w 1947 r. (s. 3-28).

\section{ROZUMIENIE WYCHOWANIA I ROLI WYCHOWAWCY}

Chcąc odpowiedzieć na pytanie: za sprawą czego poglądy pedagogiczne tego wyjątkowego dominikanina wytrzymują próbę czasu, warto sięgnąć po konkluzję Mikołaja Krasnodębskiego. Według niego

\footnotetext{
Pedagogika Woronieckiego osadzona jest na realizmie bytowym i teoriopoznawczym, głosi konieczność integralnego oraz uniwersalnego wychowania i wykształcenia człowieka. [...] Realizuje zadania wyznaczone jej przez filozofię. Celem wychowania jest więc zaszczepienie w wychowanku siły woli, dzięki której będzie on mógł realizować obiektywne cele swojego życia. Istota pedagogiki leży w tym, by nauczyć wychowanka 'chcenia - prawidłowego chcenia', tzn. usprawnić jego wolę tak, by dokonywała wyboru obiektywnego dobra, czyli 'prawdy o dobru' (Krasnodębski, 2009, s. 36-37),
}

która czyni życie ludzkie autentycznym. Nie sposób konkluzji tej nie przyznać racji, podobnie jak nie można zanegować potrzeby zgłębienia znajomości myśli etyczno-pedagogicznej o. J. Woronieckiego. Wszak centralnym zagadnieniem jego pedagogiki jest problem ludzkiego „ja”, które poszukuje tego, co je konstytuuje, jak również problematyka sprawności i cnót. Zagadnienie sprawności należy do najbardziej podstawowych i najważniejszych w etyce wychowawczej, gdyż usprawnienie woli stanowi właściwą istotę wychowania, aczkolwiek się do tego nie ogranicza. W rozumieniu o. Woronieckiego, wychowanie obejmując intelekt, wolę, uczucia i popędy człowieka, jawi się jako „wypadkowa dwóch czynników, wewnętrznej pracy każdej jednostki nad sobą (chodzi o samowychowanie) i zewnętrznych wpływów wychowawczych". Jak zauważa komentujący tę kwestię o. A. Potocki 
(2000, s. 120), Woroniecki „przyznaje, że nie zawsze łatwo je zharmonizować, tak, iżby szły po jednej linii”. Zaś

wychowaniu przypisuje dwa zadania: zdobycie rozeznania w zasadach postępowania moralnego oraz właściwe wychowanie polegające na wyćwiczeniu wszystkich władz człowieka, zarówno pożądawczych, jak i poznawczych w stosunku do działalności praktycznej (Potocki, 2000, s. 120-121).

Z władz poznawczych zaleca ćwiczenie rozumu tak, aby ten mógł kierować życiem, był wychowany do rządzenia, uzbrojony w roztropność, rozwagę, rozsądek. Jednak postęp wychowania nie polega, jak w wykształceniu, na systematycznym nabywaniu wiadomości o rzeczach zewnętrznych, lecz na wyćwiczeniu i przygotowaniu wszystkich władz do jednolitej działalności mającej na uwadze cel ostateczny, jakim jest świętość. Także władze pożądawcze (wola i uczucia) muszą być wyćwiczone i ujęte w pewne formy, żeby harmonijnie działać i zapewnić postępowaniu jedność, stałość i pewność. De facto chodzi tu nie tylko o wychowanie intelektu w formie władz zmysłowych i umysłowych, ale o wychowanie prawego sumienia, wolności, odpowiedzialnego działania i woli chcenia, gdzie wola jest wychowywana swoistymi metodami i nie jest traktowana jako przejaw myślenia, podlegający prawom rozwoju władz poznawczych (Potocki, 2000, s. 121). Ujmując osobę w sposób integralny, Woroniecki zwraca uwagę zarówno na sprawności wrodzone (niektóre cechy temperamentu, emocjonalność czy też afektywność), jak i nabyte, które osiąga się na drodze wychowania i samowychowania. Sprawności rozumu i woli, które nazywa cnotami, wyznaczają w procesie wychowania jednolitość postępowania moralnego, a postępowanie to nazywane jest charakterem moralnym. Podstawowymi cnotami, które tworzą ów charakter, są cztery cnoty kardynalne (roztropność, sprawiedliwość, męstwo i umiarkowanie) i trzy cnoty teologiczne (wiara, nadzieja i miłość). Sprawnościami przeciwnymi cnotom są wady. Skłaniają one człowieka do czynów złych i usposabiają do zła moralnego. Sprawności moralne - dodatnie i ujemne - przenikają się nawzajem, a stopień tego przenikania jest uzależniony od obecności lub braku wysiłku, jaki powinien mieć miejsce w człowieku w procesie wychowania lub samowychowania. Sprawności moralne mają to do siebie, że nas tylko do czegoś skłaniają, całkowicie nie zniewalając. Ma to podstawowe znaczenie w kształtowaniu charakteru moralnego, który jest budowany poprzez poszczególne cnoty, a niszczony przez wady moralne. Formowanie tego charakteru dokonuje się poprzez swoistą grę, zachodzącą między usprawnianiem cnót a eliminowaniem wad. 
Woroniecki, za św. Tomaszem z Akwinu, wyróżnia siedem wad głównych: pychę, łakomstwo, nieczystość, chciwość, lenistwo, zazdrość i gniew. Powyższy podział wad nie jest wyłącznie wynikiem rozważań teoretycznych, ale pochodzi z doskonałej obserwacji życia ludzkiego, która przyczynić się może do bardziej systematycznej walki ze złem i usuwania poszczególnych wad z natury ludzkiej (Woroniecki, 1938, s. 242).

Kończąc analizy przywołujące rozumienie wychowania u Woronieckiego, powołam się na jeszcze jedno ważne spostrzeżenie, jakie czyni jego współbrat o. A. Potocki. Dotyczy ono faktu, że wychowanie nie odbywa się in abstracto. U Woronieckiego nie wychowuje się jakiegoś wyizolowanego człowieka, który pod każdą szerokością geograficzną jest taki sam. Wychowuje się człowieka konkretnego i usytuowanego w określonym środowisku, w określonych okolicznościach. Stąd wychowanie uwzględniać powinno właściwości każdego narodu i predyspozycje każdego człowieka (Potocki, 2000, s. 121).

Jeśli chodzi o wychowawcę, w koncepcji o. Jacka Woronieckiego do ważnych cech jego charakteru należy całkowite panowanie nad sobą, które wyraża się jako: wytrwałość, cierpliwość i długomyślność, następnie stanowczość, surowość, duża konsekwencja w postępowaniu, wreszcie życzliwość dla młodzieży, łagodność, wyrozumiałość i uprzejmość w zewnętrznych formach obcowania wobec jej braków. Woroniecki mówi też o ważności panowania wychowawcy nad gniewem i niecierpliwością, zwłaszcza nad językiem. Widzi potrzebę panowania nad smutkiem i zniechęceniem. $\mathrm{W}$ pracy $\mathrm{z}$ młodzieżą potrzebne jest poczucie humoru, którego nasi wychowawcy mają wciąż zbyt mało, potrzebne są obok patosu radość i przygoda. Brak radości jest sygnałem braku uzdolnień do roli wychowawcy. Woroniecki akcentuje też umiejętność przydzielania nagród i kar i daje wyraz przekonaniu, że faktycznie wychowuje każdy człowiek i to we wszystkich okolicznościach, o ile jego zachowanie nacechowane jest odpowiedzialnością za wpływy, które wywiera na innych.

Należy mieć nadzieję, że nawet tak fragmentarycznie przywołane założenia uniwersalnej i humanistycznej pedagogii o. Jacka Woronieckiego, która zakłada integralne wychowanie i kształcenie człowieka, wskazują na jej niebagatelne znaczenie. Wszak jego pedagogika nie jest zarezerwowana jedynie dla katolików, chrześcijan czy osób dobrze urodzonych. Pedagogice tej przyświeca troska o integralny rozwój człowieka, moralne ukształtowanie jego woli i charakteru (Woroniecki, 1961, s. 17). 
Jego pedagogika, czerpiąc z dorobku myśli chrześcijańskiej i klasycznej myśli greckiej, łączy w harmonijną całość jednostkę i społeczeństwo, twórczy rozwój i szacunek dla uniwersalnych norm i wartości. Jest to pedagogika, która podkreśla znaczenie osobistej relacji między wychowawcą a wychowankiem i skierowana jest na osobiste i społeczne doskonalenie się osób ze świadomością potrzeby odnoszenia wszystkiego, co nam się wydarza i co nas spotyka do Boga jako ostatecznej instancji. Aktualność omawianej tu pedagogiki należałoby jednak rozpatrywać na tle wielorako manifestującego się obecnie kryzysu antropologicznego pociągającego za sobą kryzys wychowania, manifestujący się na różne sposoby. Odczytywanie myśli pedagogicznej Woronieckiego, w którą wpisane jest poszukiwanie prawdy ludzkiego oblicza, staje się sposobnością do weryfikacji wielu pytań i wątpliwości dotyczących naszego życia i tego, co spotykamy w otaczającej nas rzeczywistości zdominowanej „filozofią”: egoizmu, konsumpcjonizmu i hedonizmu. Staje się sposobnością przemyślenia na nowo ważnych kwestii związanych z naszą egzystencją, tożsamością, dobrem wspólnym i tym, co my wnosimy $\mathrm{w}$ edukację, życie społeczne, kulturowe, rodzinne i religijne w miejscu, w którym żyjemy. Nie ulega wątpliwości, że Woroniecki w sobie właściwy sposób zaprasza nas do poważnego traktowania naszego człowieczeństwa i potrzeby wychowania, intensywnego przeżywania rzeczywistości i poważnego traktowania relacji z Chrystusem.

\section{BIBLIOGRAFIA}

BeDnARSKI, F.W. (1982). Zagadnienia pedagogiczne. Londyn: Katolicki Ośrodek Wydawniczy Veritas.

BouŻYK, M.M. (2015). Myśl pedagogiczna Jacka (Adama) Woronieckiego w wybranych publikacjach z okresu 1903-1918. Polska Myśl Pedagogiczna, 1, 221-240.

BoużYK, M.M. (2016). Jacek Woroniecki o modlitwie jako czynniku doskonalącym naturę ludzką. Rocznik Tomistyczny, 357-373.

Człowiek - moralność - wychowanie. Życie i myśl Jacka Woronieckiego (2000), red. J. Gałkowski, M.L. Niedziela. Lublin: Towarzystwo Naukowe KUL.

CzUPRYN, B. (1999). Antropologiczne podstawy teorii wychowania według Woronieckiego. Człowiek $w$ Kulturze, 12, 23-29.

GaŁkowski, S. (1998). Ku dobru. Aktualność filozofii wychowania Jacka Woronieckiego. Rzeszów: Wydawnictwo Wyższej Szkoły Pedagogicznej.

GaŁkowski, S. (2003). Rozwój i odpowiedzialność. Antropologiczne podstawy koncepcji wychowania moralnego. Lublin: Wydawnictwo KUL.

Horowski, J. (2007). Paedagogia perennis $w$ dobie postmodernizmu: wychowawcze koncepcje o. Jacka Woronieckiego a kultura przełomu XX i XXI wieku. Toruń: Adam Marszałek. 
HoROwSKI, J. (2016). Wstyd a rozwój moralny: o antropologicznych fundamentach neotomistycznej teorii wychowania moralnego. Polska Myśl Pedagogiczna, 2, 231-244.

JABŁOŃSKA, J.L. (1996). Autorytet wychowawcy w koncepcjach pedagogicznych Heleny Radlińskiej i o. Jacka Woronieckiego OP. Kultura i Edukacja, 4, 93-104.

KALINOWSKA, K. (1999). „Nie grzebać w przeszłości, ale z całym zapałem patrzeć w przyszłość” - na 50. rocznicę śmierci o. Jacka Woronieckiego. Paedagogia Christiana, 4, 177-187.

KAmiŃSKA, W. (2000). O poszukiwaniu idei paedagogiae perennis we współczesnym modelu edukacyjnym. W: J. GAŁKOWSKI, M.L. NiedZIELA OP (red.), Człowiek - moralność - wychowanie. Życie i myśl Jacka Woronieckiego OP (s. 137-144). Lublin: Towarzystwo Naukowe KUL.

KAROLEwICZ, G. (2006). Ojciec Jacek Woroniecki (1878-1949) jako wychowawca inteligencji katolickiej. W: E.J. KRYŃSKA (red.), Idealy wychowania $i$ wzory osobowe narodu polskiego w XIX i XX wieku, t. 2 (s. 149-158). Białystok: Trans Humana.

KARPIŃSKA, B. (2002). Aktualności „Katolickiej etyki wychowawczej” Jacka Woronieckiego OP. Pedagogika Spoleczna, 3, 126-132.

KIEREŚ, B. (2017). Człowiek i wychowanie: od osoby do osobowości. Lublin: Wydawnictwo KUL.

KostKIEwicz, J. (2009). Potencjalność podmiotu wychowania w ujęciu antropologii katolickiej. Acta Universitatis Nicolai Copernici, Nauki Humanistyczno-Społeczne, Pedagogika, 25, 11-27.

KostKiewicz, J. (2013). Kierunki i koncepcje pedagogiki katolickiej w Polsce 1918-1939. Kraków: Oficyna Wydawnicza „Impuls”.

KrasnodęBSKI, M. (2009). Pedagogika Jacka Woronieckiego i Feliksa Wojciecha Bednarskiego jako egzemplifikacja etyki tomizmu tradycyjnego. Studia Etckie, 11, 29-58.

KRÓL, R. (2015). Klasyczny ideat wychowania w kręgu wartości tradycyjnych. Warszawa-Łódź: Heliodor.

MarchlewicZ, L. (1999). Koncepcja pedagogiki w pismach o. Jacka Woronieckiego (18781949). Życie i Myśl, 4, 91-94.

OlBRYCht, K. (2007). O roli przyktadu, wzoru, autorytetu i mistrza w wychowaniu osobowym. Toruń: Adam Marszałek.

PolaK, R. (1999). Jacek Woroniecki - życie i twórczość naukowa. Człowiek i Kultura, 12, 214-240.

PolaK, R. (1999). Jacka Woronieckiego głos w sprawie programów szkolnych, cech osobowych nauczyciela oraz zadań wychowawczych szkoły w okresie II Rzeczypospolitej. Człowiek w Kulturze, 12, 45-62.

Polak, R. (2004). Jacka Woronieckiego pedagogia cnót. Cywilizacja, nr 10, 137-147.

PolaK, R. (2011). Woroniecki Jacek Adam. W: Encyklopedia filozofii polskiej, t. 2 (s. 838-841). Lublin: Polskie Towarzystwo Tomasza z Akwinu.

PolAK, R. (2017). Człowiek i moralność w myśli Jacka Woronieckiego OP. Filozoficzne podstawy katolickiej etyki wychowawczej i jej zasady. Warszawa-Radzymin: Wydawnictwo von borowiecky.

PотоскI, A. (2000). Problemy wychowawcze w publicystyce Jacka Woronieckiego OP. W: J. GAŁKOWSKI, M.L. NiedzIEla (red.), Człowiek - moralność - wychowanie. Życie i myśl Jacka Woronieckiego OP (s. 119-135). Lublin: Towarzystwo Naukowe KUL.

RADZCKI, K. (2011). Prowadzić w życie: antropologiczne podstawy wychowania u Jacka Woronieckiego. Wrocław: Tum Wydawnictwo Wrocławskiej Księgarni Archidiecezjalnej. 
Rembierz, M. (1999). „Sensus catholicus”: uniwersalizm, obiektywizm, realizm. Myśl filozoficzno-teologiczna i działalność pedagogiczno-duszpasterska Jacka Woronieckiego OP w rozprawach i wspomnieniach Stefana Swieżawskiego. W: Człowiek - moralność - wychowanie. Życie i myśl Jacka Woronieckiego OP (s. 207-233). Lublin: Towarzystwo Naukowe KUL.

Robaczewski, M. (1999). Doskonałość człowieka celem wychowania. Człowiek w Kulturze, 14, 31-35.

RYNIO, A., TOMCZYK, M. (2012). Sprawności moralne jako elementy konstytutywne w formowaniu moralnego charakteru człowieka w twórczości o. Jacka Woronieckiego. W: I. JAZUKIEwicz, E. KwiatKowska (red.), Sprawności moralne w wychowaniu - wyzwania i rzeczywistość (s. 13-47). Szczecin: Wydawnictwo Naukowe Uniwersytetu Szczecińskiego.

SkrzYNIARZ, R. (2017). Modlitwa i jej rozumienie w życiu studentów. Uwagi pedagogiczne. Biografistyka Pedagogiczna, 1, 295-320.

ŚLEZIŃSKI, K. (2016). Założenia realizmu ontologicznego i aksjologicznego w koncepcji wychowania Jacka Woronieckiego. Polska Myśl Pedagogiczna, 2, 175-187.

Walewander, E. (2007). Pedagogia katolicka $w$ diecezji lubelskiej 1918-1939. Lublin: Towarzystwo Naukowe KUL.

WistuBA, G. (2003). Ojca Jacka Woronieckiego pedagogia perennis. Cywilizacja,7, 235-246.

WoronieCKI, J. (1938). Wady moralne i stopnie ich nasilenia. Szkoła Chrystusowa, 9(11), 241-249.

Woroniecki, J. (1947). Program pedagogiki katolickiej. Ateneum Kapłańskie, 47, 3-28.

Woroniecki, J. (1961). Wychowanie człowieka. Pisma wybrane, wybór W.K. Szymański, opr. J. Kołątaj. Kraków: Znak.

WoroniecKi, J. (2000a). Katolicka etyka wychowawcza: Etyka Ogólna, t. 1. Lublin: Fundacja Servire Veritati Instytut Edukacji Narodowej-Wydawnictwo KUL.

WoroniecKi, J. (2000b). Katolicka etyka wychowawcza: Etyka szczegółowa, t. 2 (cz. I. i cz. II). Lublin: Fundacja Servire Veritati Instytut Edukacji Narodowej-Wydawnictwo KUL.

\section{AKTUALNOŚĆ MYŚLI PEDAGOGICZNEJ \\ O. JACKA WORONIECKIEGO}

\section{STRESZCZENIE}

Autorka artykułu przekonuje o potrzebie pamięci o osobie i nauczaniu o. Jacka Woronieckiego. W ogólności przybliża, kim był i poprzez co zasłużył sobie na pamięć potomnych. Wskazuje, na czym polegał wkład Woronieckiego w rozwój pedagogiki jako takiej, a pedagogiki katolickiej w szczególności. W tym celu przywołuje argumenty, za sprawą których poglądy o. Jacka Woronieckiego dotyczące rozumienia kwestii wychowania i roli wychowawcy czy autorytetu w wychowaniu wytrzymują próbę czasu.

Słowa kluczowe: o. Jacek Woroniecki; myśl pedagogiczna; jej oryginalność i ponadczasowość. 


\section{ADEQUACY OF PEDAGOGICAL IDEAS \\ OF FATHER JACEK WORONIECKI}

\section{SUMMARY}

The publication points at the subject of the need of father Jacek Woroniecki's person's and teaching's memory. In general, it brings closer who he was and through what he deserved posterity's remembrance. The author of the publication shows the essence of his contribution to the development of pedagogics as such and the Catholic pedagogogics in particular. Therefore she brings up the arguments which make father Jacek Woroniecki's ideas about understanding the problem of education as well as preceptor's or role model's meaning for the education stand the test of time.

Key words: Father Jacek Woroniecki; pedagogics ideas; it's orginality and timelessness. 